\title{
PENYELESAIAN SENGKETA PEMILU SEBAGAI UPAYA MEMULIHKAN KEPERCAYAAN DAN MEMPERKUAT LEGITIMASI PEMERINTAHAN DEMOKRASI
}

\author{
Firdaus \\ Universitas Sultan Ageng Tirtayasa, Banten
}

\begin{abstract}
Writing this journal using a normative approach concluded that first, that the best system of elections is a system that provides the institutional mechanisms of dispute resolution elections as a place to restore the rights of citizens are violated and restore confidence in the institution elections as a democratic institution for the formation of government legitimate and reliable; second, an outline of the disputed election in Indonesia consists of two types namely, administrative disputes and disputes over the results of elections. Procedurally, Election Suravaillance Body is an institution that is authorized to decide administrative disputes election are final and binding beyond dispute concerning the verification of Political Parties Elections and the list of candidates for members of DPR, DPD, Provincial DPRD and regency/city. Furthermore Superial Administration Court up to the level of the Supreme Court is an institution that is authorized to decide disputed election administration in particular the Commission's decision regarding the establishment of verification of Political Parties Elections and the list of candidates for members of DPR, DPD, Provincial DPRD and regency/city. Disputes dispute election results for DPR, DPD, Provincial DPRD and regency/city is the jurisdiction of the Court.
\end{abstract}

Keywords: Dispute Resolution Elections and Democracy Government Legitimacy

\begin{abstract}
abstrak
Penulisan jurnal ini menggunakan pendekatan normatif disimpulkan bahwa pertama, bahwa sebaik-baik sistem penyelenggaraan pemilu adalah sistem yang menyediakan mekanisme kelembagaan penyelesaian sengketa pemilu sebagai tempat memulihkan hak-hak warga negara yang terlanggar dan mengembalikan kepercayaan institusi pemilu sebagai institusi demokrasi bagi terbentuknya pemerintahan yang legitimate dan terpercaya; kedua, secara garis besar sengketa pemilu di Indonesia terdiri dari dua jenis yakni, sengketa administrasi dan perselisihan hasil pemilihan umum. Secara prosedural, BAWASLU adalah lembaga yang berwenang memutus sengketa
\end{abstract}


administrasi pemilu yang bersifat final dan mengikat di luar sengketa mengenai verifikasi Partai Politik Peserta Pemilu dan daftar calon tetap anggota DPR, DPD, DPRD provinsi, dan DPRD kabupaten/kota. Selanjutnya PTTUN hingga tingkat MA adalah lembaga yang berwenang memutus sengketa administrasi pemilu khususnya keputusan KPU mengenai penetapan verifikasi Partai Politik Peserta Pemilu dan daftar calon tetap anggota DPR, DPD, DPRD provinsi, dan DPRD kabupaten/kota. Sengketa perselisihan hasil pemilihan umum anggota DPR, DPD, DPRD provinsi, dan DPRD kabupaten/kota adalah lingkup kewenangan MK.

Kata Kunci: Penyelesaian Sengketa Pemilu dan Legitimasi Pemerintahan Demokrasi

\section{A. Pendahuluan}

Sebaik-baik sistem penyelenggaraan pemilu dirancang di dalamnya selalu ada kemungkinan terjadi pelanggaran yang dapat mereduksi kualitas pemilu. Untuk itu sebaik-baik sistem penyelenggaraan pemilu, di dalamnya senantiasa tersedia mekanisme kelembagaan terpercaya untuk menyelesaikan berbagai jenis keberatan dan sengketa pemilu. Mekanisme kelembagaan tidak hanya sekedar menyelesaikan sengketa pemilu tetapi menjadi tempat memperjuangkan dan melindungi hak-hak warga negara dari pelanggaran. Pada saat yang sama juga berfungsi sebagai lembaga memperbaiki dan meluruskan kembali sekaligus memulihkan marwah pemilu sebagai landasan terbentuknya legitimasi pemerintahan yang terpercaya. Mekanisme sistem penyelenggaraan pemilu yang rumit disertai informasi dan tingkat pengetahuan yang lemah terhadap penyelesaian sengketa pemilu tidak jarang menjadi sumber masalah dalam menangani kasus-kasus sengketa pemilu yang dapat berujung pada instabilitas sosial politik.

Sengketa pemilu merupakan rangkaian penyelesaian dan pemulihan atas terjadinya pelanggaran pemilu. Pelanggaran pemilu dapat terjadi sejak perencanaan, persiapan, tahapan hingga perhitungan suara hasil pemilu. Pelanggaran dapat berupa pelanggaran administrasi dan pelanggaran pidana. Pelanggaran administrasi berlangsung di seputar pemenuhan hak setiap warga negara untuk berpartisipasi dalam pemilu baik sebagai pemilih maupun untuk dipilih, baik calon perorangan maupun partai politik. Tidak jarang warganegara yang telah memenuhi syarat tidak terdaftar sebagai pemilih dan atau sebaliknya tidak sedikit warga negara yang belum memenuhi syarat atau telah meninggal dunia terdaftar sebagai pemilih atau pemilih ganda. Luaran atas permasalahan tersebut berimplikasi pada daftar pemilih, hak memilih, dan perhitungan suara. Tidak terdaftarnya seseorang dalam daftar pemilih dapat berimplikasi terhadap hilangnya hak pilih 
seseorang yang sangat fundamental dalam negara hukum demokrasi. Selanjutnya daftar pemilih yang tidak bertuang dapat dimanfaatkan untuk berbuat curang berupa penggelembungan suara untuk memenangkan pihakpihak tertentu.

Bentuk-bentuk kecurangan lain dapat berlangsung dalam proses tabulasi suara dan penentuan calon-calon terpilih. Di bawah sistem suara terbanyak mendorong, tidak sedikit calon anggota legislatif melakukan perdagangan suara dengan berkonspirasi bersama penyelenggara pemilu serta calon-calon lain dalam satu partai maupun luar partai yang dapat mengubah posisi perolehan suara para calon untuk keluar sebagai pemenang dalam penentuan perolehan kursi. Selain mencederai kualitas proses pemilu, juga mendistorsi hak-hak rakyat serta mengorbankan hak-hak calon lain yang semestinya terpilih. Rangkaian pelanggaran, baik pelanggaran administrasi, maupun pelanggaran pidana memiliki derajat kesalahan dan implikasi yang berbeda dari kasus ke kasus terhadap kualitas penyelenggaraan pemilu. Masalah fundamental yang paling berbahaya adalah ketika publik meragukan hasil pemilu. Selain dapat mendeligitimasi juga dapat menimbulkan sikap antipati terhadap pemerintahan yang terpilih. Bahkan lebih jauh dapat mengganggu stabilitas sosial, politik, dan pemerintahan.

Besarnya ekspektasi masyarakat terhadap pemilu sebagai sarana revolusi politik dan pemerintahan, mendorong beberapa negara di dunia yang tengah dalam konsolidasi demokrasi membentuk institusi-insitusi, tidak saja penyelenggara pemilu yang independen tetapi juga mekanisme kelembagaan yang dapat menyelesaikan keberatan dan rasa tidak puas terhadap berbagai pelanggaran selama dalam proses hingga hasil perhitungan suara dan penentuan calon terpilih. Umumnya negara-negara di dunia termasuk Indonesia membagi dua term penyelesaian sengketa pemilu yakni: pertama, penyelesaian sengketa yang terjadi selama dalam proses tahapan pemilu; dan kedua, penyelesaian sengketa hasil pemilu. Term penyelesaian sengketa selama dalam proses pemilu diselesaikan baik melalui KPU, BAWASLU, dan PT TUN untuk aspek-aspek yang berdimensi administrasi, sedangkan pelanggaran pidana dengan kategori tertentu dapat dilakukan di tingkat pengadilan negeri. Selanjutnya term penyelesaian hasil sengketa hasil pemilu dan penetapan calon terpilih menjadi kompetensi Mahkamah Konstitusi.

\section{B. Pembahasan}

\section{Berbagai Standar Penyelesaian Keberatan dan Sengketa Pemilu}

Tidak sedikit kelompok reformis dan revolusioner di dunia berhasil meruntuhkan rezim otoriter tetapi gagal dalam melakukan konsolidasi demokrasi hingga mengalami krisis politik berkepanjangan. Seperti 
dianalogikan oleh mantan Ketua Divisi Hak-hak Sipil Bagian Pemungutan Suara Departemen Kehakiman Amerika Serikat (Voting Section of The Civil Rights Divisionat The United States Department of Justice), Barry H. Weinberg dengan menyatakan, seringkali jauh lebih mudah para anggota keluarga menyetujui meruntuhkan rumah tua mereka dibanding menyetujui desain rumah baru mereka. ${ }^{1}$ Kegagalan bukan karena ketidaksuksesan melakukan reformasi konstitusi dalam menata sistem ketatanegaraan secara menyeluruh tapi lebih disebabkan oleh teknis penyelenggaraan pemilu yang tidak terencana dengan baik dengan perangkat sistem kelembagaan yang kurang memadai dalam menjamin dan melindungi hak suara setiap warga negara dalam proses pemilu yang jujur dan adil. Artinya sistem penyelenggaraan pemilu yang baik bukan saja karena kesuksesan memungut suara tetapi harus mampu menjamin bahwa suara dari setiap warga negara sampai dan didengar melalui perhitungan yang akurat dan benar hingga ditetapkannya calon-calon terpilih. Oleh sebab itu, performa sistem penyelenggaraan pemilu yang baik, sejauh mungkin dapat mengantisipasi dan meminimalisir terjadinya pelanggaran dan sengketa pemilu. Jikapun berbagai pelanggaran dan keberatan hingga berakhir dengan sengketa sulit dihindari, tetapi senantiasa tersedia mekanisme kelembagaan yang kapabel, transparan, akuntabel, efisien, efektif, sederhana, dan berkepastian dalam menyelesaikan berbagai keberatan dan sengketa untuk memulihkan hak-hak warga negara yang terlanggar dan kepercayaan terhadap pemilu serta pemerintahan terpilih. Kesederhanaan proses penyelesaian sengketa pemilu tidak hanya terletak pada hukum acara atau proseduralnya saja tetapi juga terkait dengan substansi pengaturan setiap tahapan pemilu yang jelas sebagai tolok ukur dalam menilai setiap materi gugatan dan pembuktian.

Secara umum prinsip dasar penyelesaian keberatan dan sengketa pemilu bertujuan untuk menjamin dan memastikan bahwa hak-hak setiap warga negara untuk berpartisipasi dalam pemerintahan demokrasi tersampaikan dan didengar. Tidak sedikit ketentuan-ketentuan internasional maupun nasional lahir untuk melindungi dan menjamin terpenuhinya hakhak asasi manusia termasuk hak untuk berpartisipasi dalam memilih dan dipilih dalam pemerintahan. Di antaranya Pasal 25, International Covenan Civil and Political Rights, yang berketentuan sebagai berikut ${ }^{2}$ :

\footnotetext{
${ }^{1}$ Chad Vickery (ed.), Pedoman Untuk Memahami, Menangani, dan Menyelesaikan Sengketa Pemilu, International Foundation for Electoral Systems (IFES), 2011, hlm. xix.

${ }^{2}$ Ifdhal Kasim (ed.), Hak Sipil dan Politik; Esai-esai Pilihan, Buku Satu, (Jakarta: Lembaga Studi dan Advokasi Masyarakat (Elsam), 2001), hlm. 438-439. Conf. Frans Ceunfin, SVD (ed.), Hak-hak Asasi Manusia; Pendasaran Dalam Filsafat Hukum dan Filsafat Politik, (Ledalero: Maumere, 2004), hlm. 51.
} 
a. setiap warga negara mempunyai hak dan kesempatan tanpa pembedaan apapun seperti yang tersebut dalam pasal 2 dan tanpa pembatasan yang wajar;

b. ikut serta dalam menjalankan segala urusan umum, baik secara langsung maupun melalui wakil-wakil yang dipilih secara bebas; dan

c. memberikan suara dalam pemilihan dan dipilih dalam pemilihan berkala dengan hak pilih yang sama dan universal serta diadakan melalui pemungutan suara secara rahasia yang menjamin adanya pernyataan bebas dari kehendak para pemilih.

Ketentuan tersebut telah diratifikasi Indonesia melalui UndangUndang Nomor 12 Tahun 2005 tentang Pengesahan International Covenan Civil and Political Rights (Kovenan Internasional tentang Hak-hak Sipil dan Politik). Ketentuan yang lebih spesifik dan banyak menjadi rujukan dalam standar penyelenggaraan pemilu adalah Declaration on Criteria For Free and Fair Election yang diangkat secara bulat oleh Dewan Antar Parlemen pada sesi pertemuan 154 di Paris 26 Maret 1994. Secara umum materi yang diatur dalam deklarasi tersebut ditujukan untuk menjamin hak setiap warga negara secara bebas dan setara untuk ikut memilih dan dipilih tanpa membedakan latar belakang suku, agama, ras, warna kulit, dan kelompok manapun. Tiga hal yang menjadi perhatian utama deklarasi tersebut adalah: pertama, voting and elections rights (hak-hak pemilihan dan pemungutan suara); kedua, candidature, party, campaign rights and responsibilities (pencalonan, partai, dan hak-hak kampanye dan tanggungjawab); dan ketiga, the rights and responsibility of states (hak-hak dan tanggung jawab negara). ${ }^{3}$ Hak-hak pemilihan dan pemungutan suara meliputi:

a. every adult citizen has the right to vote in elections, on a nondiscriminatory basis;

b. every adult citizen has the right to access to an effective, impartial and non-discriminatory procedure for the registration of voters;

c. no eligible citizen shall be denied the right to vote or disqualified from registration as a voter, otherwise than in accordance with objectively verifiable criteria prescribed by law, and provided that such measures are consistent with the state's obligations under international law;

$d$. every individual who is denied the right to vote or to be registered as a voter shall be entitled to appeal to a jurisdiction competent to review such decisions and to correct errors promptly and effectively;

e. every voter has the right to equal and effective access to a polling station in order to exercise his or her right to vote;

\footnotetext{
${ }^{3}$ Goodwin Gill, Guy S., Free and Fair Election, (Geneva: Inter-Parliamentary Union, 2006), hlm. vii-xi.
} 
f. every voter is entitled to exercise his or her right equally with others and to have his or her vote accorded equivalent weight to that of others; and

$g$. the right to vote in secret is absolute and shall not be restricted in any manner whatsoever.

Hak dan tanggung jawab pencalonan, partai, dan kampanye ditujukan guna melindungi hak-hak untuk dipilih, berpartai, dan berkampanye guna memperoleh dukungan dan keuntungan untuk berpartisipasi dan mengambil bagian dalam penyelenggaraan pemerintahan. Hak-hak dan tanggung jawab pencalonan (hak dipilih), berpartai dan berkampanye meliputi antara lain:

a. everyone has the right to take part in the government of their country and shall have any equal opportunity to become a candidate for election. the criteria for participation in government shall be determined in accordance with national constitutions and laws and shall not be inconsistent with the state's international obligations;

$b$. everyone has the right to join, or together with others to establish, a political party or organization for the purpose of competing in an election;

c. everyone individually and together with others has the right: -to express political opinions without interference; -to seek, receive and impart information and to make an informed choice; -to move freely within the country in order to campaign for election; -to campaign on an equal basis with other political parties, including the party forming the existing government;

d. every candidate for election and every political party shall have an equal opportunity of access to the media, particularly the mass communications media, in order to put forward their political views.

1) the right of candidates to security with respect to their lives and property shall be recognized and protected;

2) every individual and every political party has the right to the protection of the law and to a remedy for violation of political and electoral rights;

3) the above rights may only be subject to such restrictions of an exceptional nature which are in accordance with law and reasonably necessary in a democratic society in the interests of national security or public order (ordre public), the protection of public health or morals or the protection of the rights and freedoms of others and provided they are consistent with states' obligations under international law. permissible restrictions on candidature, the creation and activity of political parties and campaign rights shall not be applied so as to violate the principle of nondiscrimination on grounds of race, color, sex, language, religion, political or other opinion, national or social origin, property, birth or other status; 
4) every individual or political party whose candidature, party or campaign rights are denied or restricted shall be entitled to appeal to a jurisdiction competent to review such decisions and to correct errors promptly and effectively;

5) candidature, party and campaign rights carry responsibilities to the community. in particular, no candidate or political party shall engage in violence;

6) every candidate and political party competing in an election shall respect the rights and freedoms of others; and

7) every candidate and political party competing in an election shall accept the outcome of a free and fair election.

Pada bagian ketiga atau bagian akhir dari deklarasi tersebut menekankan tanggung jawab negara dalam menjamin terselenggaranya pemilihan yang bebas dan jujur dengan beberapa ketentuan sebagai berikut:

a. states should take the necessary legislative steps and other measures, in accordance with their constitutional processes, to guarantee the rights and institutional framework for periodic and genuine, free and fair elections, in accordance with their obligations under international law. In particular, States should:

1) establish an effective, impartial and non-discriminatory procedure for the registration of voters;

2) establish clear criteria for the registration of voters, such as age, citizenship and residence, and ensure that such provisions are applied without distinction of any kind;

3) provide for the formation and free functioning of political parties, possibly regulate the funding of political parties and electoral campaigns, ensure the separation of party and state, and establish the conditions for competition in legislative elections on an equitable basis;

4) initiate or facilitate national programmes of civic education, to ensure that the population are familiar with election procedures and issues.

$b$. in addition, States should take the necessary policy and institutional steps to ensure the progressive achievement and consolidation of democratic goals, including through the establishment of a neutral, impartial or balanced mechanism for the management of elections. In so doing, they should, among other matters:

1) ensure that those responsible for the various aspects of the election are trained and act impartially, and that coherent voting procedures are established and made known to the voting public;

2) ensure the registration of voters, updating of electoral rolls and balloting procedures, with the assistance of national and international observers as appropriate; 
3) encourage parties, candidates and the media to accept and adopt a code of conduct to govern the election campaign and the polling period;

4) ensure the integrity of the ballot through appropriate measures to prevent multiple voting or voting by those not entitled thereto; and

5) ensure the integrity of the process for counting votes.

c. states shall respect and ensure the human rights of all individuals within their territory and subject to their jurisdiction. in time of elections, the state and its organs should therefore ensure:

1) that freedom of movement, assembly, association and expression are respected, particularly in the context of political rallies and meetings;

2) that parties and candidates are free to communicate their views to the electorate, and that they enjoy equality of access to State and publicservice media; and

3) that the necessary steps are taken to guarantee non-partisan coverage in state and public-service media.

d. in order that elections shall be fair, states should take the necessary measures to ensure that parties and candidates enjoy reasonable opportunities to present their electoral platform;

$e$. states should take all necessary and appropriate measures to ensure that the principle of the secret ballot is respected, and that voters are able to cast their ballots freely, without fear or intimidation;

f. furthermore, state authorities should ensure that the ballot is conducted so as to avoid fraud or other illegality, that the security and the integrity of the process is maintained, and that ballot counting is undertaken by trained personnel, subject to monitoring and/or impartial verification;

g. states should take all necessary and appropriate measures to ensure the transparency of the entire electoral process including, for example, through the presence of party agents and duly accredited observers;

h. states should take the necessary measures to ensure that parties, candidates and supporters enjoy equal security, and that state authorities take the necessary steps to prevent electoral violence; and

$i$. states should ensure that violations of human rights and complaints relating to the electoral process are determined promptly within the timeframe of the electoral process and effectively by an independent and impartial authority, such as an electoral commission or the courts.

Perhatian Deklarasi Pemilu Bebas dan Jujur terhadap tiga poin di atas, secara tidak langsung memposisikan ketiga bagian tersebut merupakan simpul-simpul krusial yang sangat potensil terjadi pelanggaran dalam tahapan proses penyelenggaraan pemilu. Perlakuan yang baik dengan penuh kehati-hatian terhadap ketiga poin beserta turunannya dapat meminimalisir keberatan dan sengketa pemilu. Sekalipun setiap poin menuntut adanya 
yurisdiksi berwenang, mandiri, adil, jujur, dan tidak memihak yang dapat menyelesaikan jika terjadi keberatan dan sengketa, tetapi jika didalami ketiga poin tersebut memberikan penekanan bahwa penyelesaian keberatan dan sengketa yang baik adalah mencegah sedini mungkin agar tidak terjadi pelanggaran melalui mekanisme kerja penyelenggara pemilu yang independen, profesional, transparan, akuntabel, efesien, dan efektif.

Meskipun demikian, perangkat lembaga yang berwenang untuk menyelesaikan keberatan dan sengketa tetap dipersiapkan sebagaimana terlihat dalam poin pertama angka 4 , dan poin kedua angka 8 . Terhadap poin ketiga angka 9 tampak mendapat penekanan yang lebih serius terutama jika terjadi kekerasan terhadap hak asasi manusia dan keberatan yang berhubungan dengan proses pemilu. Filosofi hak-hak asasi manusia yang mendasari setiap konstruksi gagasan deklarasi pemilu bebas dan jujur. Memetakan kelembagaan penyelesaian sengketa didasarkan pada derajat keseriusan pelanggaran hak-hak asasi manusia. Terhadap pelanggaran administrasi dan pelanggaran pidana ringan yang bersifat personal cukup dengan sebuah lembaga keberatan pemilu. Untuk pelanggaran terhadap proses pemilu yang terkategori besar seperti terorganisis, sistematis, dan masif serta memiliki dampak luas terhadap pelanggaran HAM dan tatanan tertib politik yang lebih luas, penyelesaiannya menuntut sebuah lembaga yang memiliki otoritas besar oleh lembaga peradilan yang mandiri, adil, jujur, dan tidak memihak.

Cukup banyak model penataan kelembagaan penyelesaian keberatan dan sengketa pemilu yang berkembang dalam praktek negara-negara di dunia. Semuanya tumbuh menurut latar belakang sejarah, sosial, politik, hukum, dan budaya dari masing-masing negara. Tidak ada format tunggal di antara banyak model yang jauh lebih sukses di banding yang lainnya. Semuanya tergantung pada kesungguhan dan kemauan politik para pihak yang terlibat didalamnya. Meskipun demikian, Robert Dahl dan Michael Clegg mengidentifikasi masalah-masalah pokok dan aspek-aspek yang harus dipertimbangkan dalam membangun sistem pemeriksaan keberatan dan sengketa di antaranya:

a. kejelasan kompetensi lembaga yang harus menerima, memeriksa, dan menyelesaikan keberatan dan sengketa pemilu dari tingkat pertama hingga tingkat banding;

b. mekanisme dan prosedur (hukum acara) mengenai kapan, di mana, bagaimana, dan dalam bentuk apa keberatan atau permohonan harus diajukan, termasuk syarat pembuktian, tenggang waktu yang rasional, dan ketat baik pengadu maupun badan yang menangani perkara;

c. persyaratan, format permohonan, dan formulir yang mudah didapatkan;

d. menentukan pihak-pihak yang dapat mengajukan permohonan keberatan dan sengketa; 
e. prinsip transparansi, meliputi pertimbangan hukum dan bukti-bukti penunjang yang jelas serta putusan yang terpublikasi dengan baik;

f. diseminasi melalui pendidikan dan pelatihan untuk meningkatkan pemahaman dan pengetahuan masyarakat dalam mengajukan permohonan keberatan dan gugatan guna memulihkan kembali kesalahan yang dapat mereduksi wibawa pemilu;

g. kejelasan kategori pelanggaran (pidana atau administrasi) beserta kejelasan jenis dan bentuk sanksi berdasarkan tingkat kesalahan, kelalaian, kesengajaan dan perilaku berulang. ${ }^{4}$ Sebagai tambahan yang perlu dipertimbangkan adalah rekruitmen personil profesional, kapabel, dan nonpartisan.

Secara garis besar, model-model kelembagaan penyelesaian keberatan dan sengketa pemilu yang berkembang di dunia dibagi dalam tiga bentuk antara lain: pertama, Badan Penyelenggara Pemilu (Election Management Body); kedua, Komisi Keberatan Pemilu (Election Complaint Commision); dan ketiga, peradilan pemilu (Electoral Tribunal).

\section{Penyelesaian Sengketa Pemilu di Indonesia}

Sengketa Pemilu menurut Pasal 257 Undang-Undang Nomor 8 Tahun 2012 tentang Pemilu Anggota DPR, DPD, dan DPRD adalah sengketa yang terjadi antar peserta Pemilu dan sengketa Peserta Pemilu dengan penyelenggara Pemilu sebagai akibat dikeluarkannya keputusan KPU, KPU Provinsi, dan KPU Kabupaten/Kota. Sengketa pemilu terdiri dua jenis yakni: pertama, sengketa administrasi; dan kedua, perselisihan hasil pemilu. Sengketa administrasi menjadi kompetensi BAWASLU dan Pengadilan Tinggi Tata Usaha Negara. Kompetensi BAWASLU menyelesaikan sengketa pemilu diatur dalam Pasal 258 ayat (2). Kewenangan tersebut dapat didelegasikan kepada BAWASLU Provinsi, Panwaslu Kabupaten/kota, Panwaslu Kecamatan, Pengawas Pemilu Lapangan, dan Pengawas Pemilu Luar Negeri seperti diatur dalam ayat (3). Jangka waktu pemeriksaan dan keputusan paling lama 12 hari sejak laporan atau temuan diterima. Tahapan penyelesaian sengketa dilakukan BAWASLU melalui pengkajian laporan atau temuan serta mempertemukan para pihak yang bersengketa untuk mencapai kesepakatan. Jika tidak tercapai kesepakatan, BAWASLU memberikan alternatif penyelesaian sengketa kepada para pihak. Keputusan BAWASLU mengenai penyelesaian sengketa kepada pihak yang bersengketa merupakan keputusan final dan bersifat mengikat. ${ }^{5}$ Aspek dikecualikan dari keputusan final dan mengikat BAWASLU adalah terkait

\footnotetext{
${ }^{4}$ Vickery, Chad (ed.), Pedoman Untuk...op.cit., hlm. 117-122.

${ }^{5}$ Conf. Undang-undang Nomor 15 Tahun 2011 tentang Penyelenggara Pemilu Pasal 73 ayat (4) huruf c menyelesaikan sengketa pemilu.
} 
dengan sengketa Pemilu yang berhubungan dengan verifikasi Partai Politik Peserta Pemilu dan daftar calon tetap anggota DPR, DPD, DPRD provinsi, dan DPRD kabupaten/kota (Pasal 259 ayat (1)). Artinya jika para pihak yang bersengketa tidak puas dengan keputusan BAWASLU mengenai verifikasi partai politik peserta pemilu dan DCT anggota DPR, DPD, DPRD provinsi, kabupaten, dan kota, dapat mengajukan gugatan tertulis kepada pengadilan tinggi tata usaha negara. Mekanisme penanganan sengketa pemilu oleh BAWASLU diatur dengan Peraturan BAWASLU RI Nomor 15 Tahun 2012 tentangTata cara penyelesaian sengketa pemilihan umum Anggota Dewan Perwakilan Rakyat, Dewan Perwakilan Daerah, dan Dewan Perwakilan Rakyat Daerah.

Penyelesaian Sengketa Tata Usaha Negara Pemilu ditempuh setelah seluruh proses sengketa administrasi di BAWASLU ditempuh dan para pihak yang belum merasa adil dengan Keputusan BAWASLU terkait verifikasi partai peserta pemilu, DCT anggota DPR, DPD, DPRD (Pasal 269 ayat (1)). Pengajuan permohonan gugatan ke PT TUN paling lama tiga hari setelah Keputusan BAWASLU ditetapkan. Tenggang waktu perbaikan gugatan paling lama tiga hari dan jika lewat dari tiga hari maka permohonan gugatan kadaluwarsa dan majelis hakim memutuskan gugatan tidak diterima. Tidak ada upaya hukum terhadap putusan gugatan tidak dapat diterima. PT TUN memeriksa dan memutus paling lama 21 hari sejak permohonan gugatan dinyatakan lengkap. Terhadap putusan PT TUN dapat diajukan permohonan kasasi ke MA paling lama 7 hari sejak tanggal diputuskan. Kasasi merupakan upaya hukum terakhir dan wajib diputuskan oleh majelis hakim paling lama 30 hari sejak permohonan diterima. ${ }^{6}$

Berbeda halnya dengan Perselisihan Hasil Pemilu atau biasa disebut dengan sengketa hasil pemilu secara khusus menjadi kompetensi Mahkamah Konstitusi sebagaimana diatur dalam Pasal 24C ayat (1) UUD 1945. Tentang kewenangan MK memutus perselisihan hasil pemilihan umum diatur lebih lanjut dalam Undang-Undang Nomor 24 Tahun 2003 tentang Mahkamah Konstitusi Pasal 10 ayat (1) huruf d. Demikian halnya penyelesaian perselisihan hasil pemilu legislatif secara spesifik diatur dalam UndangUndang Nomor 8 Tahun 2012 tentang Pemilu Anggota DPR, DPD, dan DPRD. Dalam Pasal 272 ayat (1) menentukan bahwa "Dalam hal terjadi perselisihan penetapan perolehan suara hasil Pemilu secara nasional, Peserta Pemilu dapat mengajukan permohonan pembatalan penetapan hasil penghitungan perolehan suara oleh KPU kepada Mahkamah Konstitusi. Masa tenggang permohonan pembatalan penetapan hasil perhitungan perolehan suara paling lama $3 \times 24$ jam sejak diumumkannya penetapan

\footnotetext{
${ }^{6}$ Undang-undang Nomor 8 Tahun 2011 tentang Pemilu Anggota DPR, DPD, dan DPRD, Pasal 269.
} 
perolehan suara secara nasional oleh KPU sebagaimana disebutkan dalam Pasal 272 ayat (2). Pemohon memperoleh kesempatan selama 3x24 jam untuk memperbaiki dan melengkapi permohonan jika kurang lengkap sejak permohonan diterima oleh MK. KPU, KPU Provinsi, dan KPU Kabupaten/Kota wajib menindaklanjuti putusan Mahkamah Konstitusi sebagaimana ditegaskan dalam Pasal 272 ayat (4).

Mekanisme penanganan PHPU diatur dalam Peraturan Mahkamah Konstitusi Nomor 16 Tahun 2009 tentang Pedoman Beracara Dalam Perselisihan Hasil Pemilihan Umum Anggota DPR, DPD, dan DPRD. Para pihak yang mempunyai kepentingan langsung dengan PHPU sebagai pemohon adalah perorangan warga negara Indonesia calon anggota DPD peserta pemilu, partai politik peserta pemilu, partai politik, dan partai politik lokal peserta pemilu anggota DPRA dan DPRK. KPU sebagai termohon dan dalam hal PHPU anggota DPRD Provinsi maka KPU/KIP provinsi turut termohon. Demikian selanjutnya jika PHPU terkait dengan anggota DPRD Kabupaten dan Kota maka KPU kabupaten dan kota turut tergugat. ${ }^{7}$ Objek sengketa adalah Keputusan KPU tentang penetapan hasil perhitungan perolehan suara pemilihan umum anggota DPR, DPD, dan DPRD.

\section{Penutup}

Berdasarkan uraian di atas dapat disimpulkan: pertama, bahwa sebaikbaik sistem penyelenggaraan pemilu adalah sistem yang menyediakan mekanisme kelembagaan penyelesaian sengketa pemilu sebagai tempat memulihkan hak-hak warga negara yang terlanggar dan mengembalikan kepercayaan institusi pemilu sebagai institusi demokrasi bagi terbentuknya pemerintahan yang legitimate dan terpercaya; kedua, secara garis besar sengketa pemilu di Indonesia terdiri dari dua jenis yakni sengketa administrasi dan perselisihan hasil pemilihan umum. Secara prosedural, BAWASLU adalah lembaga yang berwenang memutus sengketa administrasi pemilu yang bersifat final dan mengikat di luar sengketa mengenai verifikasi Partai Politik Peserta Pemilu dan daftar calon tetap anggota DPR, DPD, DPRD provinsi, dan DPRD kabupaten/kota. Selanjutnya PTTUN hingga tingkat MA adalah lembaga yang berwenang memutus sengketa administrasi pemilu khususnya keputusan KPU mengenai penetapan verifikasi Partai Politik Peserta Pemilu dan daftar calon tetap anggota DPR, DPD, DPRD provinsi, dan DPRD kabupaten/kota. Sengketa perselisihan hasil pemilihan umum anggota DPR, DPD, DPRD provinsi, dan DPRD kabupaten/kota adalah lingkup kewenangan MK.

\footnotetext{
${ }^{7}$ Peraturan Mahkamah Konstitusi Nomor 16 Tahun 2009 tentang Pedoman Beracara Dalam Perselisihan Hasil Pemilihan Umum Anggota DPR, DPD dan DPRD, Pasal 3.
} 


\section{Daftar Pustaka}

\section{A. Buku}

Ceunfin, Frans SVD (ed)., Hak-hak Asasi Manusia; Pendasaran Dalam Filsafat Hukum dan Filsafat Politik, Ledalero: Maumere.

Guy S, Goodwin Gill, 2006. Free and Fair Election, Geneva: InterParliamentary Union.

Kasim, Ifdhal (ed)., 2001. Hak Sipil dan Politik; Esai-esai Pilihan, Buku Satu, Jakarta: Lembaga Studi dan Advokasi Masyarakat (Elsam).

Vickery, Chad (ed)., 2011. Pedoman Untuk Memahami, Menangani, dan Menyelesaikan Sengketa Pemilu, International Foundation for Electoral Tahun 2012 Systems (IFES).

\section{B. Peraturan Perundang-Undangan}

Undang-undang Nomor 8 Tahun 2012 tentang Pemilu Anggota DPR, DPD, dan DPRD

Undang-undang Nomor 15 Tahun 2011 tentang Penyelenggara Pemilu.

Undang-undang Nomor 24 Tahun 2003 tentang Mahkamah Konstitusi.

Peraturan Mahkamah Konstitusi Nomor 16 Tahun 2009 tentang Pedoman Beracara Dalam Perselisihan Hasil Pemilihan Umum Anggota DPR, DPD dan DPRD.

Peraturan BAWASLU RI Nomor 15 tentangTata Cara Penyelesaian Sengketa Pemilihan Umum Anggota Dewan Perwakilan Rakyat, Dewan Perwakilan Daerah, dan Dewan Perwakilan Rakyat Daerah. 